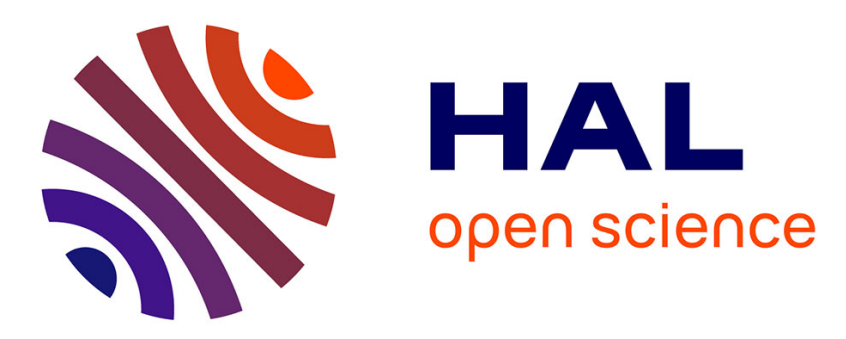

\title{
Adenosine hypersensitivity and atrioventricular block
}

Jean-Claude Deharo, Michele Brignole, Régis Guieu

\section{To cite this version:}

Jean-Claude Deharo, Michele Brignole, Régis Guieu. Adenosine hypersensitivity and atrioventricular block. Herzschrittmachertherapie and Elektrophysiologie, 2018, 29 (2), pp.166-170. 10.1007/s00399018-0570-2 . hal-01855338

\section{HAL Id: hal-01855338 \\ https://hal-amu.archives-ouvertes.fr/hal-01855338}

Submitted on 27 Aug 2018

HAL is a multi-disciplinary open access archive for the deposit and dissemination of scientific research documents, whether they are published or not. The documents may come from teaching and research institutions in France or abroad, or from public or private research centers.
L'archive ouverte pluridisciplinaire $\mathbf{H A L}$, est destinée au dépôt et à la diffusion de documents scientifiques de niveau recherche, publiés ou non, émanant des établissements d'enseignement et de recherche français ou étrangers, des laboratoires publics ou privés. 


\section{Adenosine hypersensitivity and atrioventricular block}

Adenosine, sometimes called the "retaliatory metabolite", is a ubiquitous substance that is released under several physiological and pathological conditions (e.g., in the case of myocardial hypoxia or during reflex $\beta$-adrenergic stimulation). The effects of adenosine on different structures and organs involves activation of membrane receptor subtypes, named $\mathrm{A} 1, \mathrm{~A} 2 \mathrm{~A}$, $\mathrm{A} 2 \mathrm{~B}$, or $\mathrm{A} 3$, depending on their primary sequence and affinity for ligands. The main effects of adenosine on the cardiovascular system involve the activation of $\mathrm{A} 1$ and $\mathrm{A} 2$ receptors. The activation of A1 receptors mediates cardiac depression through negative chronotropic, dromotropic, and inotropic effects [1] and diminishes blood vessel tone. The effect of adenosine on the atrioventricular (AV) node is mainly due to the stimulation of high affinity A1 receptors, which are much more numerous in the AV node than in the sinoatrial node [2]. The activation of $\mathrm{A} 2 \mathrm{~A}$ and $\mathrm{A} 2 \mathrm{~B}$ subtypes mediates artery relaxation $[3,4]$. The affinity of these receptors for adenosine depends on the receptor subtype, the affinity of A1 receptors being superior to $\mathrm{A} 2 \mathrm{~A}$ receptors, which are superior to $\mathrm{A} 2 \mathrm{~B}$ receptors. Like many other cell surface receptors, the number of adenosine receptors undergoes up-regulation and down-regulation when cardiac tissues are chronically exposed to low or elevated concentrations of adenosine receptor agonist (i.e., adenosine).

\section{Role of adenosine in neurally mediated syncope}

Several investigators have hypothesized that adenosine is an important modula- tor that can trigger vasovagal syncope in susceptible patients. From a diagnostic point of view, adenosine triphosphate injection, i.e. ATP testing, was proposed as a challenge in patients with syncope $[5,6]$. Patients with syncope of unexplained origin have been shown to have an increased susceptibility to ATP testing compared with those without syncope [5]. ATP testing was also shown to be able to reproduce atrioventricular block (AVB) in patients with spontaneous paroxysmal AVB, especially in those without abnormalities of the AV conduction or autonomic nervous system [5]. Nevertheless, the value of ATP testing as a test for syncope remains controversial due to its low specificity, and its routine use has a low level of recommendation [7]. Saadjian et al. measured adenosine plasma levels (APLs) during head-up tilt testing in 26 patients that presented with unexplained syncope [8]. Patients with a negative head-up tilt test had baseline APLs that were in the same range as those reported in normal healthy volunteers. Patients with a positive tilt test had much higher baseline levels than did patients with a negative tilt test, with no overlap between the two groups. During syncope, APLs increased by an average of 52\% compared with baseline levels. The higher the APL, the earlier the symptoms appeared and the greater the slowing of the heart rate. These observations suggest that adenosine release may be involved in the triggering mechanism of syncope induced during tilt testing. APL and A2A receptor (A2A R) expression were studied in patients with neurally mediated syncope [9]. In 46 consecutive patients with suspected neurally mediated syncope, APLs were measured and ATP and HUT tests were performed. High APL was associated with a high probability of positive HUT, while low APL was associated with a high probability of positive ATP. Expression of A2AR was lower in patients with positive ATP compared with those with positive HUT. These results suggest the presence of two distinct groups of patients with neurally mediated syncope: one with low APL and low A2AR expression and with positive ATP testing, and another with high APL, high A2AR expression, and positive HUT. Patients in the first group may be sensitive to the small increase in APL that occurs during ATP injection due to the activation of high affinity adenosine receptors (mostly A1R), leading to bradycardia. The patients from the second group are insensitive to ATP administration because most of their high affinity A1R may be desensitized by the chronic exposure to high APL. In addition, the small increase in APL that occurs after ATP administration is probably insufficient to activate lower affinity adenosine receptors (mostly A2A R); but these receptors are still activated during HUT as a result of the strong increase in APL that occurs during this test.

Translated into clinical practice, these observations can be interpreted as follows: in low-APL patients, a transient release of endogenous adenosine could be sufficient to block conduction in the $\mathrm{AV}$ node where a high number of free high-affinity A1 receptors are available; conversely, when APL is high, as in patients with vasovagal syncope or positive tilt testing, most $\mathrm{A} 1$ receptors in the $\mathrm{AV}$ node are saturated and AV block is un- 


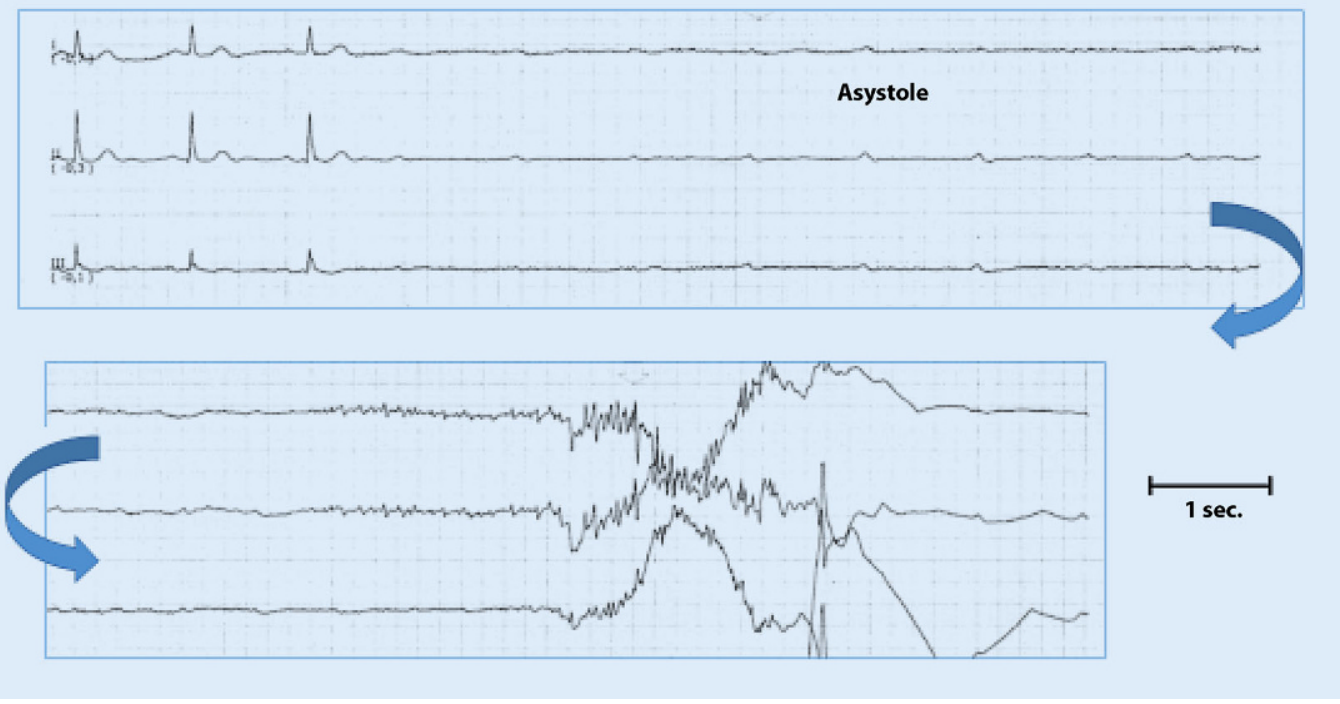

Fig. $1 \Delta$ ECG tracing recorded through in-bed telemetry monitoring during spontaneous syncope in a 72-year-old female. This patient was referred after five syncopal events that occurred in the 4 previous years. The patient never experienced prodromes and syncopal events resulted in severe trauma. She had a normal ECG and a normal electrophysiological study. ATP test was positive with a 6.3-s asystole due to atrioventricular (AV) block, and the head-up tilt test was positive, showing isolated vasodepression after nitroglycerin challenge. Adenosine plasma level (APL) was found to be extremely low $(0.15 \mu \mathrm{Mol} / \mathrm{L})$. She received a pacemaker and never experienced syncope again overnearly 10 years of follow-up, during which she did not exhibit permanent conduction abnormalities. Note the sudden onset of prolonged asystole due to complete AV block with no change in PP intervals and no escape rhythm occurrence. Jerking movements during syncope are responsible for baseline oscillations

likely to occur, while vascular A2A R activation is responsible for vasodepression.

\section{Low adenosine syndromes}

Idiopathic AV block. A new clinical entity has recently been described in a small series of patients that presented with a long history of syncope and in whom paroxysmal AV block could be recorded at the time of syncope recurrence [10]. Similar observations have been reported by others [11]. - Fig. 1 shows a typical example of such a paroxysmal AV block episode. The term "idiopathic AV block" was used since these patients had an otherwise normal heart and no sign of conduction disease on ECG and electrophysiological study. No permanent AV block was seen at any time in these patients over very long periods of follow-up. A reflex mechanism involving adenosine was suspected in these patients with very low plasma adenosine levels and a high induction rate of transient complete heart block during exogenous injections of adenosine (i.e. during ATP testing). No syncope recurrence was observed after permanent cardiac pacing. The cause of the tran- sient release of endogenous adenosine responsible for paroxysmal AV block is unknown. Idiopathic paroxysmal AV block is unique in the sense that it has different clinical and electrophysiological features from those of the two other known types of paroxysmal AV block: intrinsic AV block due to AV conduction disease and extrinsic vagal AV block. Well-defined clinical and electrophysiological features make them distinct ( $\bullet$ Table 1). Intrinsic paroxysmal AV block, which usually occurs in patients with underlying heart disease and/or abnormal standard ECG, is regarded as a manifestation of an intrinsic disease of the AV conduction system, which is confirmed by abnormal electrophysiological findings [12]. The AV block is usually initiated by atrial, His, or ventricular premature extrasystole, increased heart rate (tachy-dependent AV block), or decreased heart rate (brady-dependent AV block), all features that support a diagnosis of intrinsic AV block. The outcome is characterized by a rapid progression toward permanent AV block. Extrinsic vagal AV block is localized within the AV node and is associated with slowing of the sinus rate [13]. A classic vagal effect on the con- duction system includes gradual slowing of the sinus rate (P-P interval) and AV conduction (prolonging PR), which are occasionally followed by sinus arrest or complete AV block. The two conditions frequently coexist, indicating a simultaneous vagal action on the sinus node and AV node. Even when a more prominent $\mathrm{AV}$ response occurs, vagally mediated $\mathrm{AV}$ block is usually preceded by significant PR prolongation or Mobitz 1 periods; the $\mathrm{P}-\mathrm{P}$ interval also prolongs markedly during asystole and there is significant $P R$ prolongation on resumption of $\mathrm{AV}$ conduction. The patients affected by syncope caused by vagal AV block have different clinical features [7]. Their episodes of syncope have well-identifiable triggers and are preceded by symptoms of autonomic activation. In addition, low APL values clearly differentiate idiopathic $\mathrm{AV}$ block patients from those with vasovagal syncope. High APL values seem to characterize vasovagal syncope and tiltpositive syncope. Thus, a different basal APL profile seems to be present in patients with idiopathic AV block and in patients with vasovagal syncope. Finally, permanent cardiac pacing is successful in preventing syncopal recurrences dur- 
ing long-term follow-up in idiopathic AV block patients, but much less effective in patients affected by vasovagal cardioinhibitory syncope, even if a spontaneous asystolic reflex has been documented, with syncope recurring in $9 \%-45 \%$ of patients. The cause of persistence of syncopal recurrence in reflex syncope is attributed to the coexistence of a vasodepressor reflex which, to some degree, is present in virtually all patients.

Low adenosine syncope. Low adenosine syncope is an entity which has recently been described and enlarges the spectrum of idiopathic paroxysmal AV block. Patients that have otherwise unexplained syncope with sudden onset (i.e., without or with very short prodromes) and a normal heart and normal electrocardiogram [14] were shown to exhibit clinical, laboratory, and biological features that are very close to those observed in patients affected by idiopathic paroxysmal AV block. Unlike in vasovagal syncope patients, tilt testing is usually negative $[14,15]$. No syncope recurrence was observed after permanent cardiac pacing in 10 patients that had ECG documentation of asystolic pause due to sinus arrest or $\mathrm{AV}$ block [16]. The features distinguishing "low adenosine syncope" from vasovagal syncope are summarized in • Table 2.

\section{Adenosine levels and clinical forms of neurocardiogenic syncope}

The purinergic profile of four common forms of syncope has recently been evaluated: typical vasovagal syncope; situational syncope; carotid sinus syncope (CSS); and syncope without prodrome or with very short $(2-3 \mathrm{~s})$ prodromes and a normal heart [15]. The purinergic profile evaluation included baseline APL and characterization of A2A R expression and single nucleotide c. $1083 \mathrm{C}>\mathrm{T}$ polymorphism (SNP), which is the most common SNP in the A2A Rgene. Clinical and biological characteristics of patients and control subjects were compared. Compared to control subjects, no-prodrome and CSS patients had significantly lower APLs, while vasovagal patients had significantly higher APLs and situational

\section{J.-C. Deharo - M. Brignole · R. Guieu \\ Adenosine hypersensitivity and atrioventricular block}

syncope have recently been correlated with the clinical presentation: "low-adenosine patients," prone to asystole, may present with idiopathic atrioventricular block, carotid sinus syndrome, or syncope with no or very brief prodromes and normal heart; "high-adenosine patients," prone to vasodilation, experience vasovagal syncope. This pathophysiological classification may have therapeutic implications.

\section{Keywords}

Syncope - Atrioventricular node · Hypotension · Purinergic · Asystole

\section{Adenosinhypersensitivität und atrioventrikulärer Block}

\begin{abstract}
Zusammenfassung
Adenosin ist eine allgemein vorkommende Verbindung, die unter vielen physiologischen wie auch pathologischen Bedingungen freigesetzt wird und kardiovaskuläre Effekte hat, unter anderem auch kardioinhibitorische und vasodilatatorische. Es ist belegt, dass Adenosin als wichtiger Modulator in Bezug auf verschiedene Synkopeformen fungiert. Bei Patienten mit chronisch niedrigen Adenosinplasmaspiegeln kann eine transiente Freisetzung von endogenem Adenosin ausreichend sein, um die Erregungsleitung im atrioventrikulären (AV) Knoten zu blockieren und eine anhaltende Asystolie hervorzurufen. Umgekehrt hat die Adenosinfreisetzung bei chronisch hohen Plasmaspiegeln eine vasodepressorische Wirkung. Unterschiedliche
\end{abstract}

syncope patients had comparable APLs. Compared to controls, A2A R expression was higher in vasovagal and situational syncope patients and lower in no-prodrome patients. These findings demonstrate an association between APLs and unexplained syncope in patients without prodromes, CSS, and VVS that have profiles different from normal control subjects. Conversely, adenosine is not associated with situational syncope, which is mainly triggered by well identifiable afferent neural reflexes. These results were partly confirmed in a prospective multicenter study in which 58 patients purinerge Profile von Patienten mit Synkope sind in jüngerer Zeit mit dem klinischen Bild in Beziehung gebracht worden: Patienten mit niedrigem Adenosinspiegel neigen zu Asystolie und können einen idiopathischen AV-Block, ein Karotissinussyndrom oder eine Synkope ohne oder mit sehr kurzen Prodromen und normalem Herzen aufweisen; Patienten mit hohem Adenosinspiegel neigen zu Vasodilatation und zeigen vasovagale Synkopen. Diese pathophysiologische Klassifikation könnte von therapeutischer Relevanz sein.

\section{Schlüsselwörter}

Synkope · Atrioventrilulärknoten · Hypotonie · Purinerg · Asystolie presenting with unexplained syncope, no prodromes, and a normal heart received an implantable loop recorder (ILR) and were followed up until a diagnosis was established [16]. During an observation period of $16 \pm 13$ months, a diagnostic event was documented by the ILR in 29 patients. An asystolic pause of $11 \pm 5 \mathrm{~s}$ (range 3.5-22 s) was present at the time of the diagnostic event in 19 patients. These outcomes were compared with those of 389 patients affected by reflex syncope with prodromes who received an ILR. Compared with patients affected by reflex syncope with prodromes, pa- 
Table 1 Features distinguishing different types of paroxysmal AV block

\begin{tabular}{|c|c|c|c|}
\hline & \multirow[t]{2}{*}{ Intrinsic } & \multicolumn{2}{|l|}{ Extrinsic } \\
\hline & & Vagal & Idiopathic AVB \\
\hline Level & Below AV node & AV node & AV node \\
\hline Mechanism & Diseased tissue & Vagal tone & $\begin{array}{l}\text { Adenosine release } \\
\text { (A1R activation) }\end{array}$ \\
\hline Baseline ECG & Abnormal & Normal & Normal \\
\hline $\begin{array}{l}\text { Initiated by premature } \\
\text { beat }\end{array}$ & Yes & No & No \\
\hline Tachycardia before AVB & Possible & No & No \\
\hline \multicolumn{4}{|l|}{ Initiation } \\
\hline PP lengthening & Possible & Yes & No/modest \\
\hline PR prolongation & No & Yes & No/modest \\
\hline $\begin{array}{l}\text { Resumption of conduc- } \\
\text { tion }\end{array}$ & $\begin{array}{l}\text { Appropriately timed } \\
\text { beat }\end{array}$ & $\begin{array}{l}\text { Vagal input with- } \\
\text { drawal } \\
\text { Sinus rate accelera- } \\
\text { tion }\end{array}$ & $\begin{array}{l}\text { Spontaneous? } \\
\text { Modest sinus rate } \\
\text { acceleration }\end{array}$ \\
\hline
\end{tabular}

Table 2 Features distinguishing low adenosine syncope from vasovagal syncope

\begin{tabular}{|c|c|c|}
\hline & Low adenosine syncope & Typical vasovagal syncope \\
\hline Age & $\begin{array}{l}\text { Older patients (typically } \\
\text { over } 50 \text { years) }\end{array}$ & Younger patients \\
\hline Number of previous syncope & Typically low & Variable-May be high \\
\hline Duration of syncopal spells & Shorter (few years) & Longer \\
\hline Trauma due to syncope & Frequent & Rare \\
\hline Prodromes & Absent or very short & Longer \\
\hline Head-up tilt test & May be negative & Frequently positive \\
\hline ATP test & Frequently positive & May be negative \\
\hline Adenosine plasmatic level & $\operatorname{Low}(<0.35 \mu \mathrm{mol} / \mathrm{l})$ & High $(>0.7 \mu \mathrm{mol} / \mathrm{l})$ \\
\hline $\begin{array}{l}\text { Electrocardiographic docu- } \\
\text { mentation of syncope }\end{array}$ & $\begin{array}{l}\text { Asystole due to atrioven- } \\
\text { tricular block much more } \\
\text { frequently than to sinus } \\
\text { arrest }\end{array}$ & $\begin{array}{l}\text { Sinus bradycardia or sinus arrest } \\
\text { more frequent than atrioventricular } \\
\text { block }\end{array}$ \\
\hline $\begin{array}{l}\text { In case of atrioventricular } \\
\text { block documentation during } \\
\text { syncope }\end{array}$ & $\begin{array}{l}\text { Sudden onset, i. e. with } \\
\text { no or very slight changes } \\
\text { in PP intervals before, } \\
\text { during and after the } \\
\text { episode, without escape } \\
\text { rhythm }\end{array}$ & $\begin{array}{l}\text { Preceded by PP interval lengthen- } \\
\text { ing (or, less commonly shortening), } \\
\text { with PP prolongation during the } \\
\text { atrioventricular block episode, with } \\
\text { sinus acceleration at the time of } \\
\text { resumption of conduction }\end{array}$ \\
\hline Cardiac pacing & Highly effective & $\begin{array}{l}\text { Effective only when asystole } \\
\text { (mainly sinus arrest) is documented } \\
\text { at the time of syncope }\end{array}$ \\
\hline
\end{tabular}

tients with unexplained syncope, no prodromes, and a normal heart more frequently had asystolic syncope $(66 \%$ vs $47 \% ; P=0.001)$, and this was more frequently due to idiopathic paroxysmal atrioventricular block ( $47 \%$ vs $21 \%$; $P=0.04)$. A total of 10 patients with asystolic pauses underwent cardiac pacing, and eight patients underwent oral theophylline treatment. During the subsequent $17 \pm 12$ months of follow- ing idiopathic AV block, carotid sinus syndrome and syncope with no or very brief prodromes and normal heart; and high APL patients, prone to vasodilation, being vasovagal patients.

\section{Corresponding address}

\section{J.-C. Deharo, MD}

Service de Cardiologie, CHU La Timone

13005 Marseille, France

jean-claude.deharo@ap-hm.fr

\section{Compliance with ethical guidelines}

Conflict of interest. J.-C. Deharo, M. Brignole and R. Guieu declare that they have no competing interests.

This article does not contain any studies with human participants or animals performed by any of the authors.

\section{References}

1. Olsson RA, Pearson JD (1990) Cardiovascular purinoceptors. Physiol Rev 70(3):761-845

2. Shryock JC, Belardinelli L (1997) Adenosine and adenosine receptors in the cardiovascular system: biochemistry, physiology, and pharmacology. Am JCardiol 79(12A):2-10

3. Conti A, Monopoli A, Gamba M, Borea PA Ongini $E$ (1993) Effects of selective $A 1$ and A2 adenosine receptor agonists on cardiovascular tissues. Naunyn Schmiedebergs Arch Pharmacol 348(1):108-112

4. Karoon P, Rubino A, Burnstock G (1995) Enhanced sympathetic neurotransmission in the tail artery of 1,3-dipropyl-8-sulphophenylxanthine (DPSPX)treated rats. Br JPharmacol 116(2):1918-1922

5. Brignole M, Gaggioli G, Menozzi C, Gianfranchi L, Bartoletti A, Bottoni N, Lolli G, Oddone D, Del Rosso A, Pellinghelli G (1997) Adenosine-induced atrioventricular block in patients with unexplained syncope: the diagnostic value of ATP testing. Circulation 96(11):3921-3927

6. Flammang D, Church T, Waynberger M, Chassing A, Antiel M (1997) Can adenosine $5^{\prime}$-triphosphate be used to select treatment in severe vasovagal syndrome? Circulation 96(4):1201-1208

7. Brignole M, Moya A, de Lange FJ, Deharo JC, Elliott PM, Fanciulli A, Fedorowski A, Furlan R, Kenny RA, Martin A, Probst V, Reed MJ, Rice CP, Sutton R, Ungar A, van Dijk JG, Group ESCSD (2018) 2018 ESC Guidelines for the diagnosis and management of syncope. Eur Heart J. https://doi.org/10.1093/ eurheartj/ehy037

8. Saadjian AY, LevyS, Franceschi F, Zouher I, Paganell F, Guieu RP (2002) Role of endogenous adenosine as a modulator of syncope induced during tilt testing. Circulation 106(5):569-574

9. Deharo JC, Mechulan A, Giorgi R, Franceschi F, Prevot S, Peyrouse E, Condo J, By Y, Ruf J, Brignole M, Guieu R (2012) Adenosine plasma level and A2A adenosine receptor expression: correlation with 
laboratory tests in patients with neurally mediated syncope. Heart 98(11):855-859

10. Brignole $M$, Deharo JC, De Roy L, Menozzi C, Blommaert D, Dabiri L, Ruf J, Guieu R (2011) Syncope due to idiopathic paroxysma atrioventricular block: long-term follow-up of a distinct form of atrioventricular block. J Am Coll Cardiol 58(2):167-173

11. Tribunyan S, Israel CW, Martirosyan M (2017) Perservative paroxysmal atrioventricular block : cardiac syncope misdiagnosed as anxiety for more than 20 years. Herzschrittmacherther Elektrophysiol 28(3):335-339

12. Lee $S$, Wellens HJ, Josephson ME (2009) Paroxysmal atrioventricular block. Heart Rhythm 6(8):1229-1234

13. Alboni P, Holz A, Brignole M (2013) Vagally mediated atrioventricular block: pathophysiology and diagnosis. Heart 99(13):904-908

14. Deharo JC, Guieu R, Mechulan A, Peyrouse E, Kipson N, Ruf J, Gerolami V, Devoto G, Marre V Brignole M (2013) Syncope without prodromes in patients with normal heart and normal electrocardiogram: a distinct entity. J Am Coll Cardiol 62(12):1075-1080

15. Guieu R, Deharo JC, Ruf J, Mottola G, Kipson N, Bruzzese L, Gerolami V, Franceschi F, Ungar A, Tomaino M, lori M, Brignole M (2015) Adenosine and clinical forms of neurally-mediated syncope. JAm Coll Cardiol 66(2):204-205

16. Brignole $M$, Guieu $R$, Tomaino $M$, lori $M$, Ungar A, Bertolone C, Unterhuber M, Bottoni N, Tesi F, Deharo CJ (2017) Mechanism of syncope without prodromes with normal heart and normal electrocardiogram. Heart Rhythm 14(2):234-239 